\title{
TINJAUAN YURIDIS PENGAKHIRAN SEWA MENYEWA RUMAH YANG DIBUAT SECARA LISAN DI KELURAHAN SUNGAI BELIUNG KECAMATAN PONTIANAK BARAT
}

\begin{abstract}
Sukardi ${ }^{1}$
ABSTRAK

Seiring berjalannya waktu, perjanjian sewa menyewa yang dibuat tentunya mencapai batas waktu yang ditentukan sesuai kesepakatan kedua belah pihak. Untuk jangka waktu sewa pada perjanjian lisan diketahui pada bukti pembayaran berupa kuitansi yang didalamnya tercantum masa sewa. Perjanjian sewa menyewa diatur dalam ketentuan Buku Ketiga, Bab Ketujuh, Pasal 1548 sampai Pasal 1600 KUHPerdata. Perjanjian sewa menyewa termasuk dalam perjanjian bernama. Perjanjian ini adalah suatu perjanjian konsensuil, artinya perjanjian ini sudah sah dan mengikat pada detik tercapainya kesepakatan mengenai unsurunsur pokoknya, yaitu barang dan harga. Peraturan tentang sewa menyewa ini berlaku untuk segala macam sewa menyewa, mengenai semua jenis barang, baik barang bergerak maupun tidak bergerak, yang memakai waktu tertentu maupun yang tidak memakai waktu tertentu, karena waktu tertentu bukan syarat mutlak untuk perjanjian sewa menyewa. Sewa menyewa tidak ada penyerahan dalam arti pengalihan hak milik, yang terjadi adalah penyerahan kekuasaan atas suatu barang untuk dinikmati penyewa. Oleh karena itu, tidak dituntut atau tidak dipersyaratkan bahwa yang menyerahkan barang harus pemilik barang, sebagaimana halnya dalam perjanjian jual beli atau tukar menukar. Jadi, meskipun seseorang hanya mempunyai "hak menikmati hasil" atas suatu barang dan "bukan pemilik", yang bersangkutan sudah dapat secara sah menyewakan barang terkecuali hak menikmati hasil yang ditimbulkan dari sewa menyewa itu sendiri tanpa adanya ijin dari yang menyewakan atau perjanjian untuk sewa yang ditentukan oleh Undang-undang, seperti diperbolehkannya penyewa rumah untuk menyewakan ulang sebagian rumah yang disewanya.

Perjanjian sewa menyewa yakni merupakan perjanjian yang sederhana, dapat dibuat sendiri (akta bawah tangan) atau dibuat dihadapan notaris (akta notariil). Berdasarkan penelitian atas perjanjian sewa menyewa rumah dilapangan, terdapat klausula bahwa setelah jangka waktu sewa berakhir sedangkan penyewa tidak memperpanjang waktu sewa, maka penyewa wajib segera mengosongkan rumah tersebut dalam keadaan baik dan menyerahkan kunci rumah kepada pihak yang menyewakan.
\end{abstract}

\section{PENDAHULUAN}

Kebutuhan akan tempat tinggal merupakan tuntutan primer yang mau tidak mau harus dipenuhi. Hal ini tentunya berbenturan dengan harga tanah berikut rumah diatasnya yang tidak diimbangi dengan pendapatan yang memungkinkan untuk dapat direalisasikan. Tidak semua orang memiliki rumah sendiri yang digunakan sebagai tempat tinggal. Bagi masyarakat yang mempunyai dana terbatas, untuk mengatasi rumah sebagai tempat tinggal, ada masyarakat yang membeli dengan sistim kredit dari developer perumahan. Tidak jarang

1 Dosen Fakultas Syariah dan Ekonomi Islam 
juga masyarakat menyewa rumah dari pihak lain yang digunakan sebagai tempat tinggal atas dasar perjanjian.

Unsur utama perjanjian dalam sewa menyewa adalah adanya harga dan barang. Sewa menyewa antara pihak penyewa dan menyewakan berlaku mengikat sejak tercapainya kata sepakat (konsensus) antar kedua belah pihak.

Sewa menyewa rumah yang dilakukan didasarkan asas kebebasan berkontrak dalam mana pihak penyewa maupun pihak yang menyewakan bebas untuk memperjanjikan halhal yang ditentukan dalam perjanjian sewa menyewa yang dilakukan secara konsensuil asalkan hal-hal yang diperjanjian tidak bertentangan dengan Undang-Undang, kesusilaan dan ketertiban umum. Perjanjian sewa menyewa merupakan perjanjian konsensuil, dimana Undang Undang membedakan antara perjanjian sewa menyewa secara tertulis dan secara lisan. Sewa menyewa secara tertulis berakhir demi hukum "otomatis", yaitu bila waktu yang ditentukan habis, tanpa diperlukan pemberitahuan pemberhentian. Sedangkan sewa menyewa secara lisan berakhir, yaitu jika pihak yang menyewakan memberitahukan pada penyewa bahwa ia akan menghentikan sewanya. Pemberitahuan dilakukan dengan mengindahkan menurut kebiasaan setempat. Sewa menyewa rumah banyak terjadi di kota Pontianak, dimana pihak penyewa menginginkan rumah sebagai tempat tinggal dengan kesepakatan akan membayar sejumlah uang kepada pihak pemilik rumah dalam jangka waktu tertentu. Perjanjian yang disepakati oleh pihak penyewa dan pemilik rumah sebagai pihak yang menyewakan ada yang dibuat dalam bentuk tertulis dan secara lisan. Sewa menyewa rumah yang dituangkan dalam perjanjian tertulis secara dibawah tangan umumnya memuat hak dan kewajiban utama saja yang dibuat secara sederhana. Bahkan ada juga perjanjian mengenai sewa menyewa rumah yang dibuat secara lisan. Prosedur perjanjian sewa menyewa rumah yang biasanya dilakukan oleh masyarakat di Pontianak adalah dengan diadakannya perundingan terlebih dahulu antara pihak penyewa dengan pihak pemilik rumah untuk membuat suatu kesepakatan, yaitu tentang kesepakatan apakah si penyewa itu jadi menyewa rumah atau tidak. Hak dari pihak yang menyewakan rumah adalah menerima pembayaran uang sewa rumah tepat pada waktunya sesuai dengan yang dijanjikannya pada pemilik rumah. Menerima kembali rumah yang disewakan itu dalam keadaan rumah pada waktu seperti rumah itu diserahkan pemilik rumah kepada penyewa rumah.

Sebagai sampel lokasi penelitian, Kelurahan Sungai Beliung merupakan kawasan dengan tingkat hunian yang cukup padat. Banyak penduduk yang bermukim dikawasan tersebut menuntut mereka untuk menyediakan tempat berlindung "rumah". Untuk itu, mereka mencari rumah tempat tinggal baik dilakukan dengan cara membeli maupun dengan menyewa. Untuk fokus pada penulisan ini ditekankan pada sewa menyewa rumah yang dilakukan secara lisan. Perjanjian lisan dalam hal ini diartikan adanya kesepakatan antara pihak penyewa dengan yang menyewakan (pemilik rumah) menyangkut uang sewa dan obyek yang disewa (rumah) serta jangka waktu sewa. Dengan telah disepakati ketiga hal pokok tersebut biasanya diikuti dengan pembayaran sejumlah uang yang dibuktikan dalam kuitansi pembayaran yang didalamnya tercantum jumlah uang, lokasi rumah, dan jangka waktu sewa. Dengan adanya kuitansi tersebut, dianggap telah adanya perjanjian sewa menyewa antara kedua belah pihak tanpa harus diikuti perjanjian sewa menyewa yang lebih rinci dalam konsep perjanjian tertulis. Para pihak beranggapan dengan adanya kuitansi pembayaran telah dapat dijadikan dasar berlaku sewa menyewa rumah diantara mereka.

Seiring berjalannya waktu, perjanjian sewa menyewa yang dibuat tentunya mencapai batas waktu yang ditentukan sesuai kesepakatan kedua belah pihak. Untuk jangka waktu sewa pada perjanjian lisan diketahui pada bukti pembayaran berupa kuitansi yang didalamnya tercantum masa sewa. Umumnya, apabila masa sewa akan berakhir, pihak pemilik rumah 
(yang menyewakan) akan memberitahukan pihak penyewa bahwa masa sewa akan berakhir biasanya dilakukan menurut kebiasaan setempat sesuai waktu yang dinilai wajar/patut ataupun sesuai kesepakatan awal kedua belah pihak. Artinya dalam hal ini menuntut tanggung jawab dan kesadaran masing-masing pihak atas hak dan kewajiban yang ada pada perjanjian sewa menyewa rumah yang dilakukan.

Hambatan/kendala yang sering dijumpai dalam pelaksanaan sewa menyewa biasanya pihak penyewa pada saat berakhirnya masa sewa belum mengosongkan rumah yang disewanya, yang tentunya hal demikian merugikan pihak yang menyewakan karena tidak mendapatkan keuntungan dari barang miliknya (rumah) sedangkan disatu sisi menguntungkan pihak penyewa yang masih menikmati manfaat ekonomis dari apa yang disewanya. Hal ini tentunya berbenturan manakala pihak yang menyewakan (pemilik rumah) telah melakukan perjanjian dengan pihak lain dalam bentuk sewa menyewa yang disepakati bersama sedangkan obyek sewa masih berada pada kekuasaan pihak penyewa.

Berdasarkan uraian di atas, maka penulis tertarik untuk mengkaji "Faktor Apa Yang Menyebabkan Penyewa Rumah Tidak Mengosongkan Rumah Yang Disewanya Pada Saat Berakhirnya Masa Sewa?".

\section{PENGERTIAN PERJANJIAN SEWA MENYEWA}

Sewa-menyewa dalam bahasa Belanda disebut dengan huurenverhuur dan dalam bahasa Inggris disebut dengan rent atau hire. Sewa-menyewa merupakan salah satu perjanjian timbal balik.

Perjanjian sewa menyewa diatur dalam ketentuan Buku Ketiga, Bab Ketujuh, Pasal 1548 sampai Pasal 1600 KUHPerdata. Perjanjian sewa menyewa termasuk dalam perjanjian bernama. Perjanjian ini adalah suatu perjanjian konsensuil, artinya perjanjian ini sudah sah dan mengikat pada detik tercapainya kesepakatan mengenai unsur-unsur pokoknya, yaitu barang dan harga. Peraturan tentang sewa menyewa ini berlaku untuk segala macam sewa menyewa, mengenai semua jenis barang, baik barang bergerak maupun tidak bergerak, yang memakai waktu tertentu maupun yang tidak memakai waktu tertentu, karena waktu tertentu bukan syarat mutlak untuk perjanjian sewa menyewa.

Menurut Kamus Besar Bahasa Indonesia sewa berarti pemakaian sesuatu dengan membayar uang sewa dan menyewa berarti memakai dengan membayar uang sewa. ${ }^{2}$

Berikut ini pendapat para pakar / ahli hukum mengenai perjanjian sewa menyewa antara lain :

1. Subekti menyatakan bahwa perjanjian sewa menyewa adalah :

"Suatu persetujuan dalam pihak yang satu menyanggupkan dirinya untuk menyerahkan suatu kebendaan kepada pihak yang lain agar pihak ini dapat menikmatinya buat suatu jangka waktu tertentu pula, uang muka mana pihak yang belakangan ini sanggup membayarnya". ${ }^{3}$

2. Menurut Yahya Harahap, sewa-menyewa adalah persetujuan antara pihak yang menyewakan dengan pihak penyewa. Pihak yang menyewakan menyerahkan barang yang hendak disewa kepada pihak penyewa untuk dinikmati sepenuhnya. ${ }^{4}$

3. Menurut Wiryono Projodikoro sewa-menyewa barang adalah suatu penyerahan barang oleh pemilik kepada orang lain itu untuk memulai dan memungut hasil dari barang itu dan dengan syarat pembayaran uang sewa oleh pemakai kepada pemilik. ${ }^{5}$

2 Kamus Besar Bahasa Indonesia, hal 33

3 Subekti, Op Cit, Hal.100

4 Yahya, Harahap, Op Cit, Hal. 112

5 Wiryono Prodjodikoro, Hukum Perdata Tentang Persetujuan-Persetujuan Tertentu, (Bandung :PT. Citra 
4. Perjanjian Sewa Menyewa mendapat pengaturan secara yuridis dalam ketentuan Pasal 1548 KUHPerdata, yaitu :

Suatu persetujuan dengan mana pihak yang satu mengikatkan dirinya untuk memberikan kepada pihak yang lainnya kenikmatan suatu rumah, selama suatu waktu dan dengan pembayaran sesuatu harga yang oleh pihak tersebut belakangan itu disanggupi pembayarannya.

Berdasarkan definisi diatas, dalam perjanjian sewa-menyewa terdapat dua pihak yaitu pihak yang menyewakan dan pihak yang menyewa. Pihak yang menyewakan mempunyai kewajiban menyerahkan barangnya untuk dinikmati oleh pihak yang menyewa atau pihak penyewa. Sedangkan pihak yang menyewa atau pihak penyewa adalah membayar harga sewa.

Barang yang diserahkan dalam sewa-menyewa tidak untuk dimiliki seperti halnya dalam jual beli, tetapi hanya untuk dipakai atau dinikmati kegunaanya. Sehingga penyerahan barang dalam sewa-menyewa hanya bersifat menyerahkan kekuasaan belaka atas barang yang disewa tersebut.

Sewa menyewa adalah suatu perjanjian dimana pihak yang satu mengikatkan dirinya untuk memberikan kepada pihak yang lainnya kenikmatan dari suatu barang, dalam ketentuan waktu dan harga tertentu. Perjanjian sewa menyewa dapat dilakukan secara lisan maupun tulisan, perjanjian ini akan mengikat serta sah pada detik tercapainya kesepakatan mengenai unsur-unsur pokoknya yaitu barang dan harga. Perjanjian sewa menyewa yang dilakukan secara tertulis masa sewanya berakhir secara otomatis apabila waktu yang telah ditentukan telah habis tanpa diperlukan pemberitahuan pemberhentian terhadapnya (Pasal $1570 \mathrm{KUH}$ Perdata), dan bila perjanjian sewa menyewa dilakukan secara lisan maka perjanjian berakhir pada saat pihak yang menyewakan memberitahu kepada pihak penyewa bahwa si pemberi sewa akan menghentikan sewanya. Pemberitahuan dalam perjanjian ini sangat penting dikarenakan terkait dengan jangka waktu, karena jika tidak ada sebuah pemberitahuan maka sewa tersebut dianggap telah diperpanjang (Pasal 1571 KUH Perdata). Perjanjian sewa menyewa merupakan perjanjian yang sederhana, dapat dibuat sendiri (akta bawah tangan) atau dibuat dihadapan notaril (akta notariil). Adapun klausula penting yang harus ada dalam perjanjian ini adalah sebagai berikut:

1. Subjek perjanjian atau para pihak, yaitu si penyewa dan pihak yang menyewakan;

2. Objek yang diperjanjikan, yaitu rumah yang disewakan dengan penjelasan detail mengenai letak, luas, barang serta fasilitas yang ada dalam rumah tersebut;

3. Jangka waktu sewa menyewa, yaitu waktu dimulainya sewa dan kapan sewa menyewa berakhir, apakah dapat diperpanjang secara otomatis atau harus terdapat persetujuan terlebih dahulu dari pihak yang menyewakan;

4. Harga sewa serta cara pembayaran sewa tersebut;

5. Tanggung jawab atas fasilitas yang ada, seperti pembayaran listrik, air, telepon, ataupun bilamana terjadi kerusakan dan perbaikan pada rumah yang ditempati selama masa sewa;

6. Larangan kepada pihak penyewa untuk menyewakan kembali bangunan yang disewa kepada pihak ketiga tanpa ijin atau persetujuan dari pihak yang menyewakan serta larangan untuk mengubah bentuk bangunan tanpa ijin tertulis dari pemilik asli;

7. Syarat-syarat yang membatalkan perjanjian seperti jika terjadi keadaan kahar (force majeur) contoh gempa, banjir, perang dan sebagainya; dan

Aditya Bakti, 1981), Hal. 190 
8. Ketentuan terhadap mekanisme penyelesaian bilamana terjadi perselisihan, ada yang menggunakan mekanisme musyawarah untuk mufakat atau dengan menunjuk pengadilan negeri dimana objek sewa berada.

Perjanjian sewa menyewa rumah merupakan suatu perjanjian konsensuil yang artinya sudah sah apabila telah ada kesepakatan mengenai unsur pokoknya yaitu rumah dan harga sewa. Perjanjian sewa menyewa bertujuan untuk memberikan hak kebendaan, tapi hanya memberikan hak perseorangan terhadap orang yang menyewakan rumah untuk dinikmati dan bukannya hak milik atas rumah.

\section{SUBYEK DAN OBYEK PERJANJIAN SEWA MENYEWA}

a. Subjek hukum dalam perjanjian adalah segala sesuatu yang menurut hukum dapat menjadi pendukung (dapat memiliki) hak dan kewajiban. Yang dapat dikategorikan sebagai Subjek Hukum adalah Manusia (Natuurlijk persoon) dan Badan Hukum (Rechts persoon).

b. Subyek dari perjanjian sewa menyewa adalah para pihak yang terlibat dalam perjanjian sewa menyewa yaitu pihak yang menyewakan dan pihak penyewa. Pihak yang menyewakan adalah orang atau badan hukum yang menyewakan rumah kepada pihak penyewa, sedangkan pihak penyewa adalah orang atau badan hukum yang menyewa rumah dari pihak yang menyewakan.

c. Wiryono Prodjodikoro mengemukakan, pihak-pihak yang terlibat dalam Perjanjian sewamenyewa adalah:

1. Pihak yang menyewakan

2. Pihak Penyewa

d. Pihak yang menyewakan adalah orang atau badan hukum yang menyewakan barang atau benda kepada pihak lainya untuk menikmati kegunaan benda tersebut kepada penyewa. Pihak yang menyewakan barang atau benda tidak harus pemilik benda sendiri tetapi semua orang yang atas dasar hak penguasaan untuk memindahkan pemakaian barang ke tangan orang lain. Hal tersebut dikarenakan didalam sewa-menyewa yang diserahkan kepada pihak penyewa bukanlah hak milik atas suatu barang melainkan hanya pemakaian atau pemungutan atas hasil dari barang yang disewakan.

e. Pihak penyewa adalah orang atau badan hukum yang menyewa barang atau benda dari pihak yang menyewakan. ${ }^{6}$

f. Dengan demikian, subyek dalam perjanjian sewa menyewa meliputi yang menyewakan / menyerahkan baik itu pemilik barang atau tidak perlu pemilik barang dalam artian seseorang yang mempunyai hak menikmati hasil atas suatu barang sudah "dapat" dengan persyaratan tertentu secara sah menyewakan barang tersebut. Di pihak yang lain, yaitu yang menerima serta menikmati barang yang disewa tersebut dengan memberikan imbalan/ harga sewa.

g. Meskipun sewa menyewa rumah adalah suatu perjanjian konsensuil, namun oleh Undang Undang diadakan perbedaan (dalam akibat-akibatnya) antara perjanjian sewa menyewa rumah secara tertulis dan sewa menyewa secara lisan. Jika perjanjian sewa menyewa itu diadakan secara tertulis, maka sewa menyewa rumah berakhir demi hukum atau (otomatis), apabila waktu yang ditentukan telah habis, maka tanpa diperlukan sesuatu pemberitahuan pemberhentian untuk itu. Sebaliknya sewa menyewa rumah itu dibuat dengan lisan, maka

6 Ibid 
sewa menyewa itu tidak berakhir pada waktu yang ditentukan, melainkan jika pihak yang menyewakan harus memberitahukan kepada penyewa bahwa ia akan menghentikan sewanya. Pemberitahuan mana harus dilakukan dengan mengindahkan jangka waktu yang diharuskan menurut kebiasaan setempat. Jika tidak ada pemberitahuan seperti itu, maka dianggaplah bahwa sewa menyewa diperpanjang untuk waktu yang sama.

h. Meskipun waktunya telah ditentukan tetapi tidak dibuat secara tertulis maka perjanjian sewa menyewa rumah tidak berakhir tepat pada waktunya. Berakhirnya perjanjian sewa menyewa rumah setelah ada pemberitahuan dari salah satu pihak yang hendak mengakhirinya sewa menyewa tersebut. Sedangkan perjanjian sewa menyewa rumah baik tertulis atau tidak tertulis mengenai waktunya tidak ditentukan maka penghentiannya dan berakhirnya sewa menyewa rumah berjalan sampai saat yang dianggap pantas oleh kedua belah pihak. Pihak yang menyewakan tidak boleh mengakhiri sewa atas alasan mau dipakai sendiri rumah yang disewakan, kecuali ditentukan lebih dahulu dalam perjanjian (Pasal 1579 KUHPerdata).

i. Obyek hukum dalam perjanjian adalah segala sesuatu yang bermanfaat bagi subjek hukum dan dapat menjadi obyek dalam suatu hubungan hukum. Obyek hukum berupa benda atau barang ataupun hak yang dapat dimiliki dan bernilai ekonomis. Dapat dibedakan antara lain benda berwujud dan tidak berwujud serta benda bergerak dan tidak bergerak. Obyek sewa menyewa berupa barang tak bergerak dan barang bergerak. Dengan syarat barang yang disewakan adalah barang yang halal, artinya tidak bertentangan dengan Undangundang, ketertiban, dan kesusilaan.

j. Sebagai obyek perjanjian, jenis barang yang disewakan tidak dibatasi jenisnya. Tidak hanya benda tidak bergerak seperti tanah dan bangunan tetapi juga benda-benda bergerak seperti dinyatakan pada Pasal 1549 KUHPerdata alinea terakhir yang masih diberlakukan yaitu; "Semua jenis barang, baik yang tak bergerak, baik yang bergerak dapat disewakan". k. Pasal 1576 KUHPerdata, penjualan obyek sewa tidak memutuskan ikatan sewa menyewa yang dibuat sebelumnya. Pengertian penjualan diartikan luas sebagai pemindahan hak atas obyek, misalnya, tukar menukar, hibah, pewarisan, dan sebagainya.

\section{Hak dan Kewajiban Yang Melekat Pada Perjanjian Sewa Menyewa}

Perjanjian sewa menyewa merupakan salah satu perjanjian bernama yaitu perjanjian yang tercantum dan diatur dalam KUHPerdata yang terdiri dari Perjanjian Jual Beli, Perjanjian Tukar Menukar, Perjanjian Sewa Menyewa, Perjanjian untuk Melakukan Pekerjaan, Perjanjian Persekutuan, Perjanjian Perkumpulan, Perjanjian Penitipan Barang, Perjanjian Pinjam Pakai dan Perjanjian Pinjam Meminjam. Seperti halnya perjanjian jual beli, perjanjian sewa menyewa merupakan perjanjian yang memperoleh pengaturan yang terperinci dari dalam KUHPerdata.

Apabila perjanjian jual beli memerlukan pengaturan yang terperinci karena berkaitan dengan peralihan kepemilikan sehingga terdapat banyak permasalahan hukum yang mungkin timbul, perjanjian sewa menyewa berkaitan dengan beralihnya penggunaan manfaat selama jangka waktu tertentu, sehingga akan banyak menimbulkan permasalahan hukum yang berkaitan dengan benda yang diperjanjikan selama perjanjian berjalan dan saat berakhirnya perjanjian.

Perbedaan dengan perjanjian jual beli adalah dalam sewa menyewa tidak ada penyerahan dalam arti pengalihan hak milik, yang terjadi adalah penyerahan kekuasaan atas suatu barang untuk dinikmati penyewa. Oleh karena itu, tidak dituntut atau tidak dipersyaratkan bahwa yang menyerahkan barang harus pemilik barang, sebagaimana halnya dalam perjanjian jual beli atau tukar menukar. Jadi, meskipun seseorang hanya mempunyai 
"hak menikmati hasil" atas suatu barang dan "bukan pemilik", yang bersangkutan sudah dapat secara sah menyewakan barang terkecuali hak menikmati hasil yang ditimbulkan dari sewa menyewa itu sendiri tanpa adanya ijin dari yang menyewakan atau perjanjian untuk sewa yang ditentukan oleh Undang-undang, seperti diperbolehkannya penyewa rumah untuk menyewakan ulang sebagian rumah yang disewanya.

KUHPerdata menempatkan pengaturan terhadap sewa menyewa pada Bab Ketujuh tentang Sewa Menyewa yang merupakan bagian dari Buku Ketiga tentang Perikatan. Dapat dikemukakan hak dan kewajiban para pihak dalam perjanjian sewa menyewa, sebagai berikut :

\section{1) Hak dan Kewajiban Pihak Yang Menyewakan}

Adapun yang menjadi hak dari pihak yang menyewakan adalah menerima harga sewa yang telah ditentukan. Sedangkan yang menjadi kewajiban bagi pihak yang menyewakan dalam perjanjian sewa menyewa tersebut, yaitu:

a. Menyerahkan barang yang disewakan kepada si penyewa (Pasal 1550 ayat 1 KUHPerdata);

b. Memelihara barang yang disewakan sedemikian rupa, sehingga dapat dipakai untuk keperluan yang dimaksudkan (Pasal 1550 ayat 2 KUHPerdata);

c. Memberikan hak kepada penyewa untuk menikmati barang yang disewakan (Pasal 1550 ayat (3) KUHPerdata);

d. Melakukan pembetulan pada waktu yang sama (Pasal 1551 KUHPerdata);

e. Menanggung cacat dari barang yang disewakan (Pasal 1552 KUHPerdata).

Berikut ini diuraikan secara rinci kewajiban Pihak Yang Menyewakan sebagaimana ketentuan Pasal-pasal yang terdapat dalam KUHPerdata.

a. Pasal 1551 KUHPerdata, pihak yang menyewakan wajib untuk menyerahkan barang yang disewakan dalam keadaan terpelihara segala-galanya;

b. Pasal 1552 KUHPerdata, selama waktu sewa, ia harus menyuruh melakukan pembetulanpembetulan yang perlu dilakukan pada barang yang disewakan, kecuali pembetulan yang menjadi kewajiban penyewa. Selain itu juga pihak yang menyewakan harus menanggung penyewa terhadap semua cacat barang yang disewakan yang merintangi pemakaian barang itu, meskipun pihak yang menyewakan itu sendiri tidak mengetahuinya pada waktu dibuat persetujuan sewa. Jika cacat-cacat itu telah mengakibatkan suatu kerugian bagi penyewa, maka pihak yang menyewakan wajib memberikan ganti rugi;

c. Pasal 1553 KUHPerdata, jika barang yang disewakan musnah sama sekali dalam masa sewa karena suatu kejadian yang tak disengaja, maka persetujuan sewa gugur demi hukum. Jika barang yang bersangkutan hanya sebagian musnah, maka penyewa dapat memilih menurut keadaan, akan meminta pengurangan harga atau akan meminta pembatalan persetujuan sewa, tetapi dalam kedua hal itu ia tidak berhak atas ganti rugi;

d. Pasal 1554 KUHPerdata, selama masa sewa berlangsung pihak yang menyewakan tidak diperkenankan selama waktu sewa, mengubah bentuk atau susunan barang yang disewakan;

e. Pasal 1555 KUHPerdata, jika dalam masa sewa pada barang yang disewakan itu terpaksa diadakan pembetulan-pembetulan yang tidak dapat ditunda sampai berakhirnya masa sewa, maka penyewa harus menerimanya betapapun beratnya kesusahan yang disebabkannya, dan meskipun selama dilakukannya pembetulan-pembetulan itu ia terpaksa kehilangan 
sebagian dari barang yang disewakan;

f. Pasal 1556 KUHPerdata, tetapi jika pembetulan-pembetulan itu berlangsung lebih lama dari empat puluh hari, maka harga sewa harus dikurangi menurut banyaknya waktu yang tersita dan bagian barang sewa yang tidak dapat dipakai oleh penyewa. Jika pembetulanpembetulan sedemikian rupa sifatnya, sehingga barang sewa yang perlu ditempati oleh penyewa dan keluarganya tak dapat didiami, maka penyewa dapat memutuskan sewanya. Selain itu pihak yang menyewakan tidak wajib menjamin penyewa terhadap rintangan dalam menikmati barang sewa yang dilakukan oleh pihak ketiga tanpa berdasarkan suatu hak atas barang sewa itu, hal ini tidak mengurangi hak penyewa untuk menuntut sendiri orang itu;

g. Pasal 1557 KUHPerdata, jika sebaliknya penyewa diganggu dalam kenikmatannya karena suatu tuntutan hukum mengenai hak milik atas barang yang bersangkutan, maka ia berhak menuntut pengurangan harga sewa menurut perimbangan, asal gangguan atau rintangan itu telah diberitahukan secara sah kepada pemilik;

h. Pasal 1559 KUHPerdata, jika orang-orang yang melakukan perbuatan-perbuatan tersebut menyatakan bahwa mereka mempunyai suatu hak atas barang yang disewakan, atau jika penyewa sendiri digugat untuk mengosongkan seluruh atau sebagian dari barang yang disewa atau untuk menerima pelaksanaan pengabdian pekarangan, maka ia wajib memberitahukan hal itu kepada pihak yang menyewakan dan dapat memanggil pihak tersebut sebagai penanggung. Bahkan ia dapat menuntut supaya ia dikeluarkan dari perkara, asal ia menunjuk untuk siapa ia menguasai barang yang bersangkutan. Dan selama masa sewa berlangsung penyewa, jika tidak diizinkan, tidak boleh menyalahgunakan barang yang disewanya atau melepaskan sewanya kepada orang lain, atas ancaman pembatalan persetujuan sewa dan penggantian biaya, kerugian dan bunga sedangkan pihak yang menyewakan, setelah pembatalan itu, tidak wajib menaati persetujuan ulang sewa itu. Jika yang disewa itu berupa sebuah rumah yang didiami sendiri oleh penyewa, maka dapatlah ia atas tanggung jawab sendiri menyewakan sebagian kepada orang lain jika hak itu tidak dilarang dalam persetujuan.

\section{2) Hak dan Kewajiban Pihak Penyewa}

Adapun yang menjadi hak bagi pihak penyewa adalah menerima barang yang di sewakan dalam keadaan baik. Sedangkan yang menjadi kewajiban dari pihak penyewa dalam perjanjian sewa menyewa tersebut, yaitu:

a. Pasal 1560 KUHPerdata, penyewa harus menepati dua kewajiban utama memakai barang sewa sebagai seorang kepala rumah tangga yang baik, sesuai dengan tujuan barang itu menurut persetujuan sewa atau jika tidak ada persetujuan mengenai hal itu, sesuai dengan tujuan barang itu menurut persangkaan menyangkut keadaan serta membayar harga sewa pada waktu yang telah ditentukan;

b. Pasal 1561 KUHPerdata, jika penyewa memakai barang yang disewa untuk suatu keperluan lain dari yang menjadi tujuannya, atau untuk suatu keperluan yang dapat menimbulkan suatu kerugian bagi pihak yang menyewakan maka pihak ini, menurut keadaan dapat meminta pembatalan sewa;

c. Pasal 1562 KUHPerdata, jika antara pihak yang menyewakan dan pihak yang menyewa telah dibuat suatu pertelaan tentang barang yang disewakan, maka pihak yang belakangan ini wajib mengembalikan barang itu dalam keadaan seperti waktu barang itu diterima menurut pertelaan tersebut kecuali yang telah musnah atau berkurang harganya sebagai 
akibat dari tuanya barang atau sebagai akibat dari kejadian-kejadian yang tak disengaja dan tak dapat dihindarkan;

d. Pasal 1563 KUHPerdata, jika tidak dibuat suatu pertelaan maka penyewa mengenai pemeliharaan yang menjadi beban para penyewa, dianggap telah menerima barang yang disewa itu dalam keadaan baik, kecuali jika dibuktikan sebaliknya dan ia harus mengembalikan barang itu dalam keadaan yang sama;

e. Seringkali selama masa sewa berlangsung terjadi kerusakan-kerusakan yang ditimbulkan baik itu secara sengaja ataupun tidak sengaja sehingga membuat barang sewaan itu rusak dan hal ini mengakibatkan kerugian bagi pihak yang menyewakan. Untuk mengantisipasi hal yang demikian Kitab Undang-Undang Hukum Perdata memberikan suatu jaminan hukum seperti yang diatur dalam Pasal 1564, berbunyi Penyewa bertanggung jawab atas segala kerusakan yang ditimbulkan pada barang yang disewakan selama waktu sewa, kecuali jika ia membuktikan bahwa kerusakan itu terjadi di luar kesalahannya, akan tetapi ia tidak bertanggung jawab atas kebakaran, kecuali jika pihak yang menyewakan membuktikan bahwa kebakaran itu disebabkan oleh kesalahan penyewa (Pasal 1565);

f. Pasal 1566 KUHPerdata, Penyewa bertanggung jawab atas segala kerusakan atau kerugian yang ditimbulkan pada barang sewa oleh teman-temannya atau oleh mereka yang mengambil alih sewanya". Hal ini karena dalam praktek seringkali terjadi kerusakan terhadap barang-barang sewaan yang bukan karena kesalahan dari pihak penyewa melainkan karena kesalahan dari orang yang ada di dalam rumah seperti misalnya temanteman serumah, sehingga pihak penyewa mengatakan bahwa dia tidak mau memberikan ganti rugi atas barang sewaan yang sudah rusak tersebut;

g. Pasal 1567 KUHPerdata, pada waktu mengosongkan barang yang disewa, penyewa boleh membongkar dan membawa segala sesuatu yang dengan biaya sendiri telah dibuat pada barang yang disewa asal pembongkaran dan pembawaan itu dilakukan tanpa merusak barang yang disewa;

h. Pasal 1569 KUHPerdata, jika terjadi perselisihan tentang harga sewa yang dibuat secara lisan dan sudah dijalankan, sedangkan tanda bukti pembayaran tidak ada, maka pihak yang menyewakan harus dipercaya atas sumpahnya kecuali bila penyewa memilih untuk menyuruh para ahli menaksir harga sewa;

i. Pasal 1570 KUHPerdata, tidak hanya itu juga jika sewa dibuat dengan tulisan, maka sewa itu berakhir demi hukum bila waktu yang ditentukan telah lampau, tanpa diperlukan suatu pemberhentian untuk itu;

j. Pasal 1571 KUHPerdata, kemudian jika sewa tidak dibuat dengan tulisan, maka sewa itu tidak berakhir pada waktu yang ditentukan, melainkan setelah salah satu pihak memberitahukan kepada pihak yang lain bahwa ia hendak menghentikan sewanya dengan mengindahkan tenggang waktu yang diharuskan menurut kebiasaan setempat;

k. Pasal 1572 KUHPerdata, tidak hanya itu juga jika pihak yang satu.telah memberitahukan kepada pihak yang lain bahwa ia berhak menghentikan sewanya, maka penyewa meskipun ia tetap menikmati barang yang bersangkutan, tidak dapat mengemukakan adanya suatu penyewa ulang secara diam-diam;

1. Pasal 1573 KUHPerdata, jika setelah berakhir suatu penyewaan yang dibuat secara tertulis, penyewa tetap menguasai barang yang disewa dan dibiarkan menguasainya, maka terjadilah suatu sewa baru, yang akibat-akibatnya diatur dalam Pasal-pasal mengenai penyewaan secara lisan;

m. Pasal 1574 KUHPerdata, dalam hal kedua pasal tersebut di atas, penanggungan utang yang dibuat untuk penyewaan tidak meliputi kewajiban yang terjadi akibat perpanjangan sewa; 
n. Pasal 1575 KUHPerdata, persetujuan sewa sekali-kali tidak hapus dengan meninggalnya pihak yang menyewakan ataupun pihak yang menyewa;

o. Pasal 1576 KUHPerdata, dengan dijualnya barang yang disewa, sewa yang dibuat sebelumnya tidak diputuskan kecuali bila telah diperjanjikan pada waktu menyewakan barang. Jika ada suatu perjanjian demikian, penyewa tidak berhak menuntut ganti rugi bila tidak ada suatu perjanjian yang tegas, tetapi jika ada perjanjian demikian, maka ia tidak wajib mengosongkan barang yang disewa selama ganti rugi yang terutang belum dilunasi;

p. Pasal 1577 KUHPerdata, pembeli dengan perjanjian membeli kembali tidak dapat menggunakan wewenangnya untuk memaksa penyewa mengosongkan barang yang disewa, sebelum ia menjadi pemilik mutlak dengan lewatnya tenggang waktu yang ditentukan untuk pembelian kembali;

q. Pasal 1578 KUHPerdata, seorang pembeli yang hendak menggunakan wewenangnya yang diperjanjikan dalam persetujuan sewa, untuk memaksa penyewa mengosongkan barang sewa jika barangnya dijual, wajib memperingatkan penyewa sekian lama sebelumnya, sebagaimana diharuskan oleh adat setempat mengenai penghentian sewa. Dalam hal sewa tanah, peringatan tersebut harus disampaikan sedikitnya satu tahun sebelum pengosongan;

r. Pasal 1579 KUHPerdata, pihak yang menyewakan tidak dapat menghentikan sewa dengan menyatakan hendak memakai sendiri barang yang disewakan, kecuali jika telah diperjanjikan sebaliknya;

s. Pasal 1580 KUHPerdata, jika dalam persetujuan sewa telah disetujui bahwa pihak yang menyewakan akan berhak memakai sendiri rumah atau tanah yang disewakan maka ia wajib memberitahukan kehendaknya untuk menghentikan sewa sekian lama sebelumnya sebagaimana ditetapkan dalam Pasal 1578;

t. Pasal 1581 KUHPerdata, penyewa yang tidak melengkapi sebuah sewa rumah dengan perabot rumah secukupnya. dapat dipaksa untuk mengosongkan rumah itu kecuali bila ia memberikan cukup jaminan untuk pembayaran uang sewa;

u. Pasal 1582 KUHPerdata, seorang penyewa kedua tidak wajib membayar kepada pemilik lebih dari jumlah harga sewa kedua yang masih terutang kepada penyewa pertama pada waktu dilakukan suatu penyitaan. dan ia tak boleh mengajukan pembayaran yang dilakukan sebelumnya. kecuali jika pembayaran itu dilakukan menurut suatu perjanjian yang dinyatakan dalam persetujuan sewa itu atau menurut kebiasaan setempat;

v. Pasal 1583 KUHPerdata, pembetulan-pembetulan kecil sehari-hari, dipikul oleh penyewa. Jika tidak ada persetujuan mengenai hal itu maka dianggap demikianlah pembetulan pada lemari toko, daun jendela, kunci dalam, kaca jendela, baik di dalam maupun di luar rumah dan segala sesuatu yang dianggap termasuk itu, menurut kebiasaan setempat. Meskipun demikian, pembetulan-pembetulan itu harus dipikul oleh pihak yang menyewakan bila pembetulan itu terpaksa dilakukan karena kerusakan barang yang disewa atau karena keadaan yang memaksa;

w.Pasal 1584 KUHPerdata, menjaga kebersihan sumur, kolam air hujan, dan tempat buang air besar dibebankan kepada pihak yang menyewakan, jika tidak diperjanjikan sebaliknya. Menjaga kebersihan asap, jika tidak ada perjanjian dibebankan kepada pihak yang menyewa;

x. Pasal 1585 KUHPerdata, sewa mebel untuk melengkapi sebuah rumah, tempat kediaman, toko atau ruangan lainnya, harus dianggap telah dibuat untuk jangka waktu penyewaan rumah, tempat kediaman, toko atau ruangan menurut kebiasaan setempat;

y. Pasal 1586 KUHPerdata, penyewaan kamar yang dilengkapi dengan mebel harus dianggap telah dilakukan untuk tahunan, bila dibuat atas pembayaran sejumlah uang tiap tahun; untuk bulanan, bila dibuat atas pembayaran sejumlah uang tiap bulan; untuk harian, bila dibuat 
atas pembayaran sejumlah uang tiap hari. Jika tidak ternyata bahwa penyewaan dibuat atas pembayaran sejumlah uang tiap tahun, tiap bulan atau tiap hari, maka penyewaan dianggap telah dibuat menurut kebiasaan setempat;

z. Pasal 1587 KUHPerdata, jika penyewa sebuah rumah atau ruangan, setelah berakhirnya waktu yang ditentukan dalam suatu persetujuan tertulis, tetap menguasai barang sewa, sedangkan pihak yang menyewakan tidak melawannya maka dianggaplah bahwa penyewa tetap menguasai barang yang disewanya atas dasar syarat-syarat yang sama untuk waktu yang ditentukan oleh kebiasaan setempat, dan ia tidak dapat meninggalkan barang sewa atau dikeluarkan dari situ, kecuali sesudah ada pemberitahuan tentang penghentian sewa, yang dilakukan menurut kebiasaan.

\section{DATA DAN INFORMASI TENTANG PENYEWA RUMAH TIDAK MENGOSONGKAN RUMAH YANG DISEWANYA PADA SAAT BERAKHIR MASA SEWA}

Dalam keadaan yang sedang dilanda krisis multidimensi seperti yang sedang dialami negara Indonesia sekarang ini, tidak semua orang mampu memiliki sebuah rumah sendiri, sehingga berbagai usaha dilakukan untuk memenuhi kebutuhan rumah tersebut. Pemenuhan akan kebutuhan rumah bagi yang belum dan/atau tidak mampu banyak dilakukan dengan cara menyewa. Kebutuhan akan tempat yang dapat dipergunakan untuk berteduh bagi manusia merupakan suatu kebutuhan yang primer di samping kebutuhan sandang dan pangan. Pertambahan penduduk yang sangat cepat terutama di kota-kota besar, masalah kekurangan perumahan menjadi lebih parah lagi, sedangkan untuk membangun dengan cepat rumahrumah baru adalah merupakan satu-satunya jalan yang paling efektif, sebagaimana hal ini belum secara merata dapat dibangun oleh pemerintah karena melihat kebutuhan - kebutuhan lainnya yang masih sangat perlu untuk diprioritaskan, belum lagi harga rumah dan tanah yang semakin tinggi, sehingga tidak semua orang dapat menjangkau untuk membeli rumah.

Fenomena tersebut disikapi oleh para pemilik modal yang mempunyai lebih dari satu rumah untuk melakukan investasi dengan cara menyewakan kepada pihak lain yang membutuhkan rumah, sehingga terjadilah sewa menyewa rumah dimana para pihak secara bersama-sama untuk mendapatkan keuntungan. Di satu sisi pemilik rumah mempunyai keuntungan atas investasi rumah dengan cara disewakan sedangkan pihak yang menyewa juga memperoleh manfaat atas rumah yang mereka sewa tentu saja dengan harga yang lebih murah daripada mereka harus membeli rumah yang semakin hari harganya semakin tinggi.

Rumah adalah bangunan untuk tempat tinggal, atau bangunan pada umumnya (seperti gedung, dsb). Pengertian Rumah menurut Undang-undang Nomor 4 tahun 1992 tentang Perumahan dan Pemukiman, adalah selain berfungsi sebagai tempat tinggal atau hunian yang digunakan manusia untuk berlindung dari gangguan iklim atau mahluk hidup lainnya, rumah juga merupakan tempat awal pengembangan kehidupan dan penghidupan keluarga, dalam lingkungan yang sehat, aman, serasi dan, tentram.

Perjanjian sewa menyewa yakni merupakan perjanjian yang sederhana, dapat dibuat sendiri (akta bawah tangan) atau dibuat dihadapan notaris (akta notariil). Adapun klausula penting yang harus ada dalam perjanjian ini adalah sebagai berikut:

1. Subjek perjanjian atau para pihak, yaitu si penyewa dan pihak yang menyewakan;

2. Objek yang diperjanjikan, yaitu rumah yang disewakan dengan penjelasan detail mengenai letak, luas, barang serta fasilitas yang ada dalam rumah tersebut;

3. Jangka waktu sewa menyewa, yaitu waktu dimulainya sewa dan kapan sewa menyewa 
berakhir, apakah dapat diperpanjang secara otomatis atau harus terdapat persetujuan terlebih dahulu dari pihak yang menyewakan;

4. Harga sewa serta cara pembayaran sewa tersebut;

5. Tanggung jawab atas fasilitas yang ada, seperti pembayaran listrik, air, telepon, ataupun bilamana terjadi kerusakan dan perbaikan pada rumah yang ditempati selama masa sewa;

6. Larangan kepada pihak penyewa untuk menyewakan kembali bangunan yang disewa kepada pihak ketiga tanpa ijin atau persetujuan dari pihak yang menyewakan serta larangan untuk mengubah bentuk bangunan tanpa ijin tertulis dari pemilik asli;

7. Syarat-syarat yang membatalkan perjanjian seperti jika terjadi keadaan kahar (force majeur) contoh gempa, banjir, perang dan sebagainya; dan

8. Ketentuan terhadap mekanisme penyelesaian bilamana terjadi perselisihan, ada yang menggunakan mekanisme musyawarah untuk mufakat atau dengan menunjuk pengadilan negeri dimana objek sewa berada.

Perjanjian sewa menyewa rumah ini merupakan perjanjian konsesuil, dimana undangundang membedakan antara perjanjian sewa menyewa secara tertulis dan secara lisan. Dimana dapat dimungkinkan dalam suatu perjanjian pasti ada ingkar janji atau yang sering disebut wanprestasi. Hasil penelitian menunjukan bahwa prosedur perjanjian sewa menyewa rumah yang biasanya dilakukan dengan diadakannya perundingan terlebih dahulu antara pihak penyewa dengan pihak pemilik rumah (yang menyewakan) untuk membuat suatu kesepakatan, yaitu tentang kesepakatan apakah si penyewa itu jadi menyewa rumah atau tidak. Untuk lebih menjamin kepastian hukum perjanjian sewa menyewa rumah harus dibuat secara tertulis dan kalau perlu selain ditandatangani oleh pemilik rumah dengan penyewa rumah juga ditandatangani oleh dua orang saksi dan sebaiknya disahkan dihadapan pejabat yang berwenang, atau setidaknya diketahui oleh Kepala Desa atau Kelurahan setempat.

Berkenaan dengan berakhirnya jangka waktu sewa menyewa rumah, untuk mencegah timbulnya hal-hal yang tidak diharapkan dikemudian hari dan mencegah penafsiran serta makna ganda, pencantuman batas waktu berakhirnya masa sewa yang jelas sangat diperlukan. Seorang penyewa sebuah rumah, setelah berakhirnya waktu sewa yang ditentukan dalam suatu perjanjian sewa tertulis, dibiarkan menempati rumah atau ruangan tersebut, maka dianggaplah si penyewa itu tetap menguasai barang yang disewakan atas dasar syaratsyarat yang sama untuk waktu yang ditentukan oleh kebiasaan setempat, dan tak dapatlah meninggalkan rumah atau ruangan itu atau dikeluarkan dari situ, melainkan sesudahnya dilakukan pemberitahuan penghentian sewanya menurut kebiasaan setempat (Pasal 1587 KUHPerdata).

Berdasarkan penelitian atas perjanjian sewa menyewa rumah dilapangan, terdapat klausula bahwa setelah jangka waktu sewa berakhir sedangkan penyewa tidak memperpanjang waktu sewa, maka penyewa wajib segera mengosongkan rumah tersebut dalam keadaan baik dan menyerahkan kunci rumah kepada pihak yang menyewakan.

Berdasarkan pengisian kuesioner yang disebarkan kepada 10 (sepuluh) orang responden yang melakukan perjanjian sewa menyewa rumah, pada umumnya mereka beralasan kebanyakan penyewa tidak mau meninggalkan/menggosongkan rumah yang disewanya meskipun masa sewa telah berakhir karena alasan mereka tidak mempunyai / belum menemukan rumah sewa yang baru atau belum waktunya menempati rumah yang baru baik rumah yang dibeli atau rumah yang akan disewa dari pemilik rumah sewa yang lain. Keadaan ini tentunya merugikan pemilik rumah sewa karena tidak mendapatkan uang 
sewa dari penyewa rumah untuk memperpanjang masa sewa rumahnya ataupun tidak dapat menyewakan kembali kepada pihak lain yang berminat untuk menyewa rumah miliknya.

a. Alasan Penyewa Rumah Tidak Mengosongkan Rumah Yang Disewanya Pada Saat Berakhirnya Masa Sewa.

b. Sewa menyewa merupakan suatu hubungan yang biasa/wajar dalam suatu masyarakat, termasuk masyarakat Indonesia. Hubungan sewa menyewa tersebut dapat terjadi karena adanya salah satu pihak yang mempunyai rumah yang tidak sedang digunakan, sedangkan disisi lain adanya pihak yang hendak (butuh) menempati suatu rumah namun belum mampu membeli atau merasa lebih praktis apabila menyewa saja rumah yang sudah ada.

c. Hubungan sewa menyewa dari segi hukum merupakan suatu perjanjian sewa menyewa yang pengaturannya terdapat dalam Buku Ketiga Bab Ketujuh Kitab Undang-Undang Hukum Perdata (KUHPerdata).

d. Berdasarkan hasil penelitian, untuk faktor-faktor penyebab penyewa rumah tidak mengosongkan rumah yang disewanya pada saat berakhirnya masa sewa disebabkan antara penyewa belum menemukan rumah sewa yang baru tetapi tidak mau memperpanjang masa sewa rumah yang telah berakhir, pemilik rumah akan menyewakan rumahnya untuk disewakan kepada pihak lain biasanya dengan harga yang lebih tinggi akan tetapi penyewa yang lama belum mendapatkan rumah sewa yang baru dengan harga sewa sesuai dengan kemampuan finansial si penyewa, ataupun penyewa akan menempati rumah sewa yang baru akan tetapi rumah sewa yang akan ditempati belum selesai masa sewa dari penyewa yang lama.

\section{UPAYA HUKUM YANG DILAKUKAN OLEH PEMILIK TERHADAP PENYEWA RUMAH YANG TIDAK MENGOSONGKAN RUMAH YANG DISEWANYA PADA SAAT BERAKHIRNYA MASA SEWA}

Salah satu masalah yang dapat terjadi dalam hubungan hukum perjanjian sewa menyewa adalah apabila pemilik rumah hendak menyewakan lagi rumahnya, sementara si penyewa memaksakan kehendak untuk tetap tinggal atau telah habisnya masa sewa namun si penyewa menolak untuk meninggalkan rumah yang dsewanya setelah berakhirnya masa sewa merupakan wanprestasi atas perjanjian sewa menyewa dan atas wanprestasi tersebut biasanya upaya hukum yang dapat ditempuh ialah dengan mengajukan gugatan perdata wanprestasi ke Pengadilan Negeri. Namun hal ini tentunya akan membutuhkan biaya yang banyak serta waktu yang lama bagi pemilik rumah, padahal uang sewa tersebut belum tentu besar. Sementara apabila si pemilik rumah mengusir penyewa secara paksa dengan caranya sendiri, hal ini jelas merupakan suatu cara main hakim sendiri (eigenrechting) yang berlawanan dengan hukum, sehingga si pemilik rumah dapat saja digugat ke Pengadilan Negeri dengan gugatan perdata melawan hukum.

Dalam perjanjian sewa menyewa rumah, apabila si penyewa tidak mau pergi setelah berakhirnya jangka waktu yang disepakati sebelumnya atau setelah sebelumnya diberitahukan oleh yang menyewakan rumah bahwa ia tidak akan memberikan perpanjangan sewa, maka perbuatan si penyewa yang tidak mau pergi (tidak mau meninggalkan rumah sewa) merupakan suatu bentuk wanprestasi berdasarkan Pasal 1239 KUHPerdata sehingga dapat dituntut untuk memberikan penggantian biaya, rugi dan bunga tentunya setelah dilakukannya pengiriman peringatan (somasi) berdasarkan Pasal 1238 KUHPerdata. Setelah selesai dilakukannya peringatan (somasi) kepada si penyewa, dan ternyata penyewa tersebut masih tetap menolak meninggalkan rumah sewa, maka upaya hukum yang dapat dilakukan oleh pihak yang menyewakan (biasanya pemilik rumah sewa) ialah dengan menggugat secara 
perdata melalui Pengadilan Negeri setempat dengan dasar wanprestasi.

Berdasarkan analisis hukum tersebut, dapat dikemukakan sebagai langkah hukum yang ditempuh apabila penyewa rumah tidak mengosongkan rumah yang disewanya meskipun waktu sewa telah berakhir, pada dasarnya sewa menyewa masuk dalam ranah Hukum Perdata, sehingga jika timbul masalah seperti diatas dapat mengajukan gugatan secara keperdataan kepada pihak penyewa dengan gugatan perbuatan melawan hukum (on recht matigedaad) atau gugatan wanprestasi (ingkar janji / cidera janji), dengan tuntutan agar si penyewa / penghuni segera meninggalkan rumah atau bangunan tersebut tanpa syarat apapun. Gugatan ini juga dapat disertai permintaan ganti rugi oleh pemilik rumah. Namun apabila menempuh jalur hukum secara keperdataan sampai dengan putusan mempunyai kekuatan hukum yang tetap ( inkracht van gewijsde ) akan memakan waktu berbulan-bulan bahkan terkadang sampai tahunan sehingga akan merugikan pihak pemilik rumah atau kontrakan dari segi waktu. Oleh karena itu, ada cara penyelesaian yang lebih efektif yaitu diselesaikan melalui jalur pidana. Dengan demikian, pemilik rumah yang sah dapat menempuh langkah hukum secara perdata ataupun secara pidana. Apabila telah berakhir masa sewa rumah, dilakukan dengan dibuatnya surat peringatan kepada penyewa yang tidak mau meninggalkan rumah yang telah habis masa sewanya tersebut, isi dari surat tersebut jangan ada batas waktu lagi untuk meninggalkan rumah tersebut tapi tuliskan dengan kata-kata segera / secepatnya keluar / meninggalkan/menggosongkan dan dalam isi surat tersebut terdapat dasar hukum yang mengaturnya. Dengan demikian, apabila penyewa rumah tersebut tidak menepati janjinya, misalnya masa berlaku sewa rumah telah habis dan pemilik rumah yang sah tidak mau memperpanjang masa sewanya tapi penyewa tidak mau meninggalkan/mengosongkan/ keluar dari rumah tersebut dengan berbagai alasan.

Dasar hukum lain yang mengatur sewa menyewa rumah ini mendapatkan pengaturan lebih lanjut sebagaimana Peraturan Pemerintah. NOMOR 44 TAHUN 1994 TENTANG PENGHUNIAN RUMAH OLEH BUKAN PEMILIK

- Pasal 10 ayat 1 "Penyewa wajib mentaati berakhirnya batas waktu sewa sesuai dengan yang diperjanjikan".

- Pasal 10 ayat 2 "Dalam hal penyewa sebagaimana dimaksud dalam ayat (1) tidak bersedia meninggalkan dan mengosongkan rumah yang disewa sesuai dengan batas waktu yang disepakati dalam perjanjian, penghunian

- dinyatakan tidak sah atau tanpa hak dan pemilik dapat meminta bantuan Kepolisian Negara Republik Indonesia untuk mengosongkannya”.

Sebenarnya, pelaksanaan pengosongan dan pengusiran si penyewa yang beritikad buruk dapat terlaksana dengan cepat dan efisien, tanpa berlama-lama melalui gugatan perdata di Pengadilan Negeri namun juga tanpa menggunakan kekuatan (kekerasan) secara tidak melawan hukum. Upaya hukum yang dapat dilakukan oleh si pemilik rumah untuk menghadapi penyewa yang beritikad buruk ialah dengan meminta dilakukannya penertiban (pengusiran dan pengosongan paksa) kepada aparat pemerintah yang berwenang (baik kepolisian maupun satuan polisi pamong praja). Hal ini dimungkinkan berdasarkan UndangUndang Nomor 4 Tahun 1992 Tentang Perumahan Dan Permukiman khusus pada Pasal 12 ayat (5) yang berbunyi sebagai berikut :

"Dalam hal penyewa sebagaimana dimaksud dalam ayat (4) tidak bersedia meninggalkan rumah yang disewa sesuai dengan batas waktu yang disepakati dalam perjanjian tertulis, penghunian dinyatakan tidak sah atau tanpa hak dan pemilik rumah dapat meminta bantuan instansi Pemerintah yang berwenang untuk menertibkannya."

Sedangkan penjelasan ketentuan di atas ialah sebagai berikut : 
Ketentuan ini dimaksudkan untuk menjamin ketertiban dalam pemanfaatan rumah dan mempercepat pengosongan rumah sewa yang dihuni tanpa hak agar pemilik rumah terlindungi haknya. Hal ini tentunya akan menciptakan iklim yang dapat mendorong masyarakat untuk membangun rumah sewa.

Berdasarkan ketentuan diatas, sebenarnya telah jelas untuk dapat mengosongkan rumah sewa dari penyewa yang beritikad buruk, dapat saja dilakukan dengan cepat tanpa penggunaan kekerasan yang melawan hukum, yaitu dengan bantuan aparat pemerintah yang berwenang. Bahkan tidak hanya pengusiran secara langsung, penyewa yang beritikad buruk juga dapat dilaporkan kepada pihak kepolisian karena menempati rumah tanpa persetujuan atau izin pemilik.

\section{PENUTUP}

Alasan penyewa rumah tidak mau meninggalkan rumah sewa meskipun sudah habis masa sewa dikarenakan penyewa rumah belum menemukan rumah sewa yang baru sehingga memaksa mereka untuk tetap menempati rumah sewa yang lama walaupun penyewa bersangkutan tidak berniat untuk memperpanjang masa sewa karena biasanya pemilik rumah sewa sudah menyewakan rumah sewanya kepada pihak lain dengan harga sewa yang tinggi daripada harga sewa yang lama.

Upaya hukum yang dilakukan oleh pemilik rumah sewa (pihak yang menyewakan) adalah dapat mengajukan gugatan perdata wanprestasi ke Pengadilan Negeri setempat, ataupun dapat minta bantuan kepada petugas yang berwenang untuk dapat memerintahkan penyewa rumah yang masa sewanya sudah berakhir untuk mengosongkan rumah yang disewanya.

\section{DAFTAR PUSTAKA}

Departemen Pendidikan Nasional. 1992. Kamus Besar Bahasa Indonesia.Jakarta.

Krisna R.1956. Kitab UU Hukum Acara Perdata.Yokjakarta: Andiopset

Subekti.1989. Pengantar Hukum Perdata. Yogjakarta: Liberti.

Yahya Harahap.2010. Hukum Acara Perdata. Jakarta: Sinar Grafika. Wiryono Prodjodikoro. 1981.Hukum Perdata Tentang Persetujuan- Tertentu. Bandung :PT. Citra Aditya Bakti, 